ARTICLE

DOI: $10.1038 / s 41467-018-07079-z$

\title{
Neodymium isotope evidence for glacial- interglacial variability of deepwater transit time in the Pacific Ocean
}

\author{
Rong Hu (i) ${ }^{1,2} \&$ Alexander M. Piotrowski
}

There is evidence for greater carbon storage in the glacial deep Pacific, but it is uncertain whether it was caused by changes in ventilation, circulation, and biological productivity. The spatial $\varepsilon_{N d}$ evolution in the deep Pacific provides information on the deepwater transit time. Seven new foraminiferal $\varepsilon_{\mathrm{Nd}}$ records are presented to systematically constrain glacial to interglacial changes in deep Pacific overturning and two different $\varepsilon_{N d}$ evolution regimes occur spatially in the Pacific with reduced meridional $\varepsilon_{\mathrm{Nd}}$ gradients in glacials, suggesting a faster deep Pacific overturning circulation. This implies that greater glacial carbon storage due to sluggish circulation, that is believed to have occurred in the deep Atlantic, did not operate in a similar manner in the Pacific Ocean. Other mechanisms such as increased biological pump efficiency and poor high latitude air-sea exchange could be responsible for increased carbon storage in the glacial Pacific. 
eing volumetrically the largest ocean basin and most enriched in nutrients, Pacific deep water stores the largest amount of dissolved inorganic carbon in the Earth's oceanatmosphere system today and may have been an even larger carbon reservoir during the glacial periods ${ }^{1-3}$. One of the central questions is how the Pacific Ocean circulation linked to atmospheric $\mathrm{CO}_{2}$ concentration over glacial-interglacial (G-I) cycles. Previous studies in the Atlantic Ocean have attributed the enhanced respired carbon storage at the Last Glacial Maximum (LGM) to an increase in the residence time of deep Atlantic waters $^{4,5}$, but few studies have focused on the past variability of Pacific deep ocean circulation and the results are still controversial ${ }^{3,6-11}$. One of the reasons is that foraminifera tests, a primary archive of past ocean chemistry, are poorly preserved in the deep Pacific due to the presence of more corrosive deep waters. The partial dissolution of foraminifera calcite might complicate the reliable reconstruction of foraminifera-based geochemical proxies (such as $\delta^{18} \mathrm{O}, \delta^{13} \mathrm{C}, \Delta^{14} \mathrm{C}, \mathrm{Cd} / \mathrm{Ca}$ ), which otherwise would provide valuable information about the past nutrient and ventilation states of the deep oceans. These proxies are also controlled by a combination of high latitude air-sea exchange, biological production, and ocean circulation, and thus have difficulty in distinguishing whether the increased $\mathrm{CO}_{2}$ storage in the glacial deep Pacific was the result of reduced air-sea exchange in the Southern Ocean or sluggish deepwater circulation.

Neodymium isotope has been demonstrated to be an effective proxy to trace the mixing in the global deep ocean ${ }^{12-14}$. However, unlike north-south convection structure in the Atlantic, there is no deepwater formation in the North Pacific today, and the deep Pacific basin is exclusively ventilated by northward-flowing Lower Circumpolar Deep Water (LCDW). The strong linear relationships between seawater $\mathrm{Nd}$ isotope compositions and oxygen/ phosphate concentrations in the deep Pacific ${ }^{12,15}$ support the dominant role of LCDW advection and the presence of an external (i.e. not from a particular water mass) radiogenic $\mathrm{Nd}$ source which is added to the deep ocean in a nearly spatially homogenous way similar to nutrients, but not a link with the biological processes per $\mathrm{se}^{15}$. In this regard, the accumulation of external Nd input to the deep water might be time-dependant and the large-scale spatial $\mathrm{Nd}$ isotope gradients are likely to be associated with the deep Pacific circulation rate.

To better constrain the temporal and spatial Nd isotope evolution in the deep Pacific, $\mathrm{Nd}$ isotope work on seven sediment cores within a range of water depth between 600 and $4000 \mathrm{~m}$ from the southwest Pacific (SWP) and eastern/western equatorial Pacific (EEP/WEP) over the last and penultimate glacial maximum (30 and $160 \mathrm{ka}$ ) are presented in this study and compared with another $10 \varepsilon_{\mathrm{Nd}}$ records throughout the deep Pacific (Fig. 1 and Supplementary Table 1). Although different archives have been applied to extract seawater $\mathrm{Nd}$ isotope signatures in paleoceanographic reconstructions ${ }^{12}$, to avoid possible operational bias for the spatial $\varepsilon_{\mathrm{Nd}}$ gradients, the $\varepsilon_{\mathrm{Nd}}$ records investigated and compiled here are processed under a uniform technique, i.e. foraminifera with $\mathrm{Fe}-\mathrm{Mn}$ coatings ${ }^{13}$, which is demonstrated to reliably record the $\mathrm{Nd}$ isotope signatures of porewater/bottom water in the Pacific ${ }^{12,15}$. On this basis, the detrital influence on porewater $\varepsilon_{\mathrm{Nd}}$ is examined and controlling factors of $\mathrm{Nd}$ isotope evolution from different regions and different depths are summarised. Building on the hypothesis of time-dependant accumulation of external $\mathrm{Nd}$ on the LCDW pathway, a simple box model is used to quantitatively estimate the transit time over the past $160 \mathrm{ka}$. These results will have important implications on how the strength of the overturning circulation is linked to carbon storage in the deep Pacific Ocean over G-I cycles.

\section{Results}

Deglacial $\varepsilon_{N d}$ records in the Equatorial Pacific (0-30 ka). Two $\mathrm{Nd}$ isotopic records spanning the last $30 \mathrm{ka}$ were measured on the EEP intermediate-depth core V21-30 and deep WEP core V28239 (Fig. 2 and Supplementary Tables 2-3). Both foraminiferal and detrital $\mathrm{Nd}$ isotopic records of V21-30 are presented. The foraminiferal $\varepsilon_{\mathrm{Nd}}$ record shows a continually increasing trend from glacial values $-1.6 \pm 0.2$ at $24.8 \mathrm{ka}$ to $+0.1 \pm 0.2$ at $6.4 \mathrm{ka}$, and then the $\mathrm{Nd}$ isotope values start to stabilize at $\sim-1$ to $\sim 0$ in the late Holocene. However, the detrital $\mathrm{Nd}$ isotope compositions are much more radiogenic $(\sim 0$ to +4.5$)$ and evolved differently from the foraminiferal record. The largest radiogenic shift $(+2.7$ $\varepsilon_{\mathrm{Nd}}$ units) in detrital $\mathrm{Nd}$ isotopes occurred from 12.4 ka to 10.9 $\mathrm{ka}$, followed by a steadily $\varepsilon_{\mathrm{Nd}}$ decreasing trend during the Holocene, when the foraminiferal $\varepsilon_{\mathrm{Nd}}$ was in a continuous increasing evolution. Another discrepancy in these two records can be seen during the last glacial period when there was a rapid detrital $\varepsilon_{\mathrm{Nd}}$ elevation from $+0.6 \pm 0.2$ at $28.2 \mathrm{ka}$ to $+1.8 \pm 0.2$ at $27.2 \mathrm{ka}$, followed by a sharp decline to $+0.2 \pm 0.2$ at $26.7 \mathrm{ka}$, while the foraminiferal $\mathrm{Nd}$ isotope compositions showed a negative shift from $-0.9 \pm 0.2$ to $-1.4 \pm 0.2$. On the other hand, the foraminiferal $\mathrm{Nd}$ isotope compositions of the western equatorial core V28-239 are less radiogenic and showed little variability ( -3.0 to -3.6 , average $\left.\varepsilon_{\mathrm{Nd}}=-3.4 \pm 0.2\right)$ across the last $30 \mathrm{kyr}$ (Fig. 2d).

Nd isotopic records spanning the last glacial (0-160 ka). Four foraminiferal $\mathrm{Nd}$ isotopic records over the last $160 \mathrm{ka}$ are measured on two intermediate SWP sites (SO136-38 and CHAT16K) and two deep EEP sites (ODP1241 and ODP846), along with eight $\varepsilon_{\mathrm{Nd}}$ data points from RC13-114 due to limited sample availability for this core (Fig. 3 and Supplementary Tables 4-8). The $\mathrm{Nd}$ isotope compositions of the four foraminiferal records vary with core locations, with more radiogenic $\varepsilon_{\mathrm{Nd}}$ values farther north. For example, the most southerly core SO136-38 on Campbell Plateau had the least radiogenic $\varepsilon_{\mathrm{Nd}}$ values in this study, which varied between $\sim-7$ during interglacial times (MIS 1 and 5) and -5.5 during glacial periods (MIS 2 and 6). To the north of Chatham Rise, the intermediate-depth core CHAT16K had much more radiogenic $\varepsilon_{\mathrm{Nd}}$ values (average $=-3.6 \pm 0.3$ ) and less variability than SO136-38. The $\varepsilon_{\mathrm{Nd}}$ values of ODP846 in the deep EEP also did not vary much over the past $160 \mathrm{ka}$ and were generally about $1 \varepsilon_{\mathrm{Nd}}$ unit higher than CHAT16K, with an average $\varepsilon_{\mathrm{Nd}}$ value of $-2.6 \pm 0.4$. Although there are only eight $\varepsilon_{\mathrm{Nd}}$ data points for RC13-114 over the past $160 \mathrm{ka}$, these $\varepsilon_{\mathrm{Nd}}$ data (average $=-2.6 \pm 0.4$ ) match well with the nearby record of ODP846, confirming that they are recording the $\varepsilon_{\mathrm{Nd}}$ signals of the same water mass. The most northern site ODP1241 in the EEP showed the most radiogenic foraminiferal $\varepsilon_{\mathrm{Nd}}$ values in this study, ranging between -1.5 and +1 , with less radiogenic $\varepsilon_{\mathrm{Nd}}$ signatures during glacial periods (MIS 2 and 6). Unlike the foraminiferal $\mathrm{Nd}$ isotope record, the $\mathrm{Nd}$ isotopes of the detrital fractions did not change following G-I cycles. Instead, the least radiogenic detrital $\mathrm{Nd}$ isotope composition $(-2.1 \pm 0.2)$ occurred at $135 \mathrm{ka}$, whereas the most radiogenic signal appeared at late Holocene $(+4.4 \pm 0.2)$ and MIS $4(+3.3 \pm 0.1)$.

\section{Discussion}

The detrital $\varepsilon_{\mathrm{Nd}}$ values of V21-30 varied between 0 and +5 (Fig. 2c) and those of ODP1241 varied between -3 and +5 (Fig. 3c) during the studied time periods, indicating a dominant proximal source of central American arcs/Galapagos hotspot to this region ${ }^{16,17}$. The consistency of decreased detrital $\varepsilon_{\mathrm{Nd}}$ in the equatorial Pacific ${ }^{18-20}$ during the glacial periods is in accordance with globally higher continental dust loads ${ }^{21}$ from Asia, South 
a
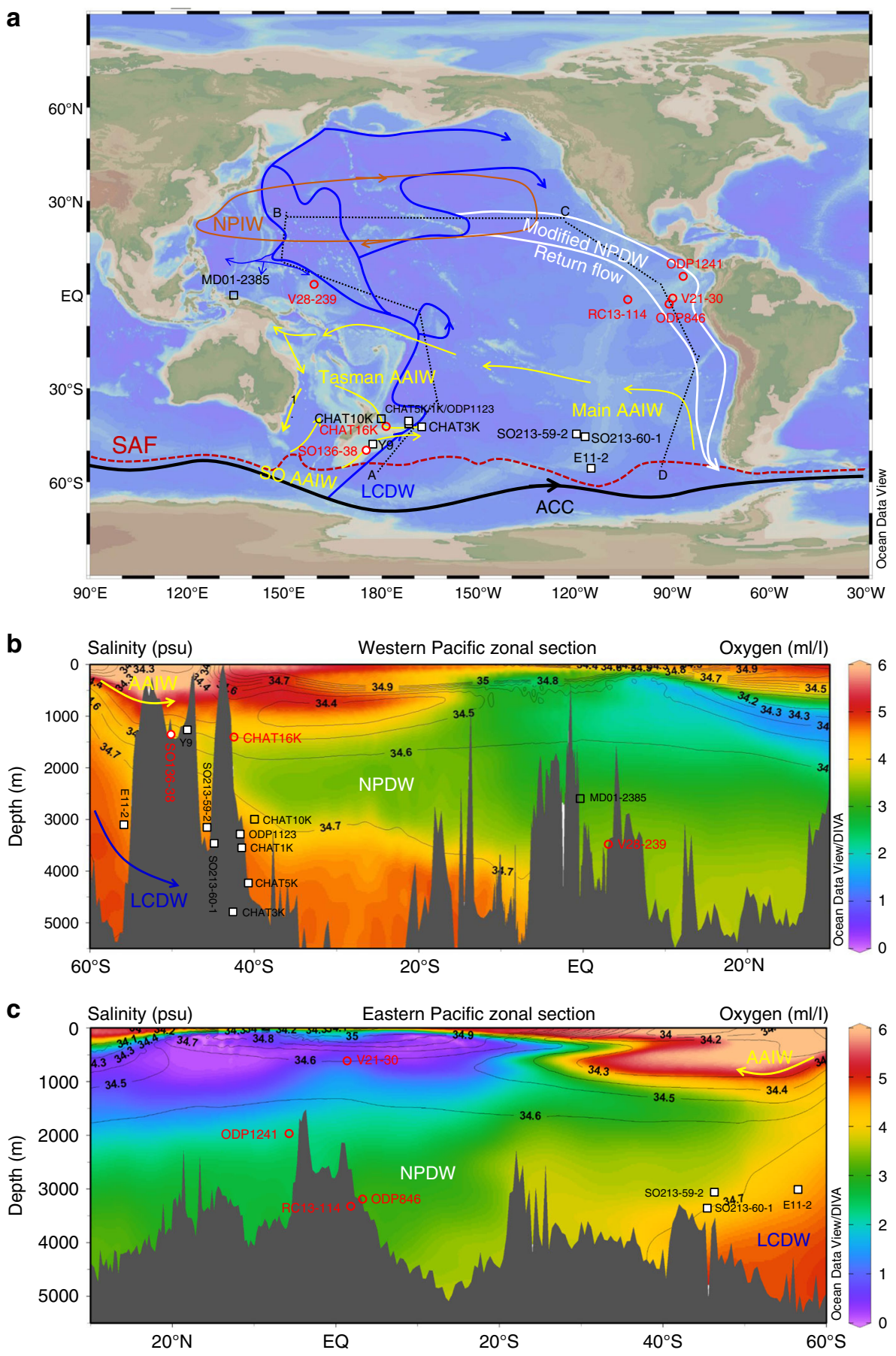

Fig. 1 Modern hydrography and core locations in the Pacific Ocean. a Map showing intermediate and deep water circulation and locations of the sediment cores from this study (red circles) and other Pacific sites (black squares) for comparison (Site locations and sources please refer to Supplementary Table 1). White filled symbols denote cores showing South Pacific-regime Nd isotope evolution patterns, while the open symbols represent cores showing North Pacific-regime patterns (see text). SAF: Subantarctic Front, ACC: Antarctic Circumpolar Current, LCDW: Lower Circumpolar Deep Water, AAIW: Antarctic Intermediate Water, NPDW: North Pacific Deep Water, NPIW: North Pacific Intermediate Water. b Western Pacific zonal section of dissolved oxygen (colour) and salinity (contours) along the dark grey dotted line from A to B in Map a. c Eastern Pacific zonal section of dissolved oxygen (colour) and salinity (contours) along the dark grey dotted line from C to D in Map a. Note that the three cores from the Central South Pacific are included in both sections solely on their latitudes and depths. Figures created using Ocean Data View Software (http://odv.awi.de)

America and/or Africa. From the perspective of Nd isotopes, the detrital sources of our EEP cores can thus be divided into two endmembers: one from young volcanic arcs with radiogenic $\varepsilon_{\mathrm{Nd}}$ signatures (average $\varepsilon_{\mathrm{Nd}}=+7$ ) 22 and the other from old continental particles with unradiogenic $\varepsilon_{\mathrm{Nd}}$ signatures (average
$\left.\varepsilon_{\mathrm{Nd}}=-10\right)^{23}$. The variation in detrital $\varepsilon_{\mathrm{Nd}}$ records of V21-30 and ODP1241 can be regarded as reflecting changing proportions of inputs from these two endmembers.

The foraminiferal $\mathrm{Nd}$ isotopic composition of the youngest material of V28-239 $(-3.3 \pm 0.1)$ matches well with that of nearby 


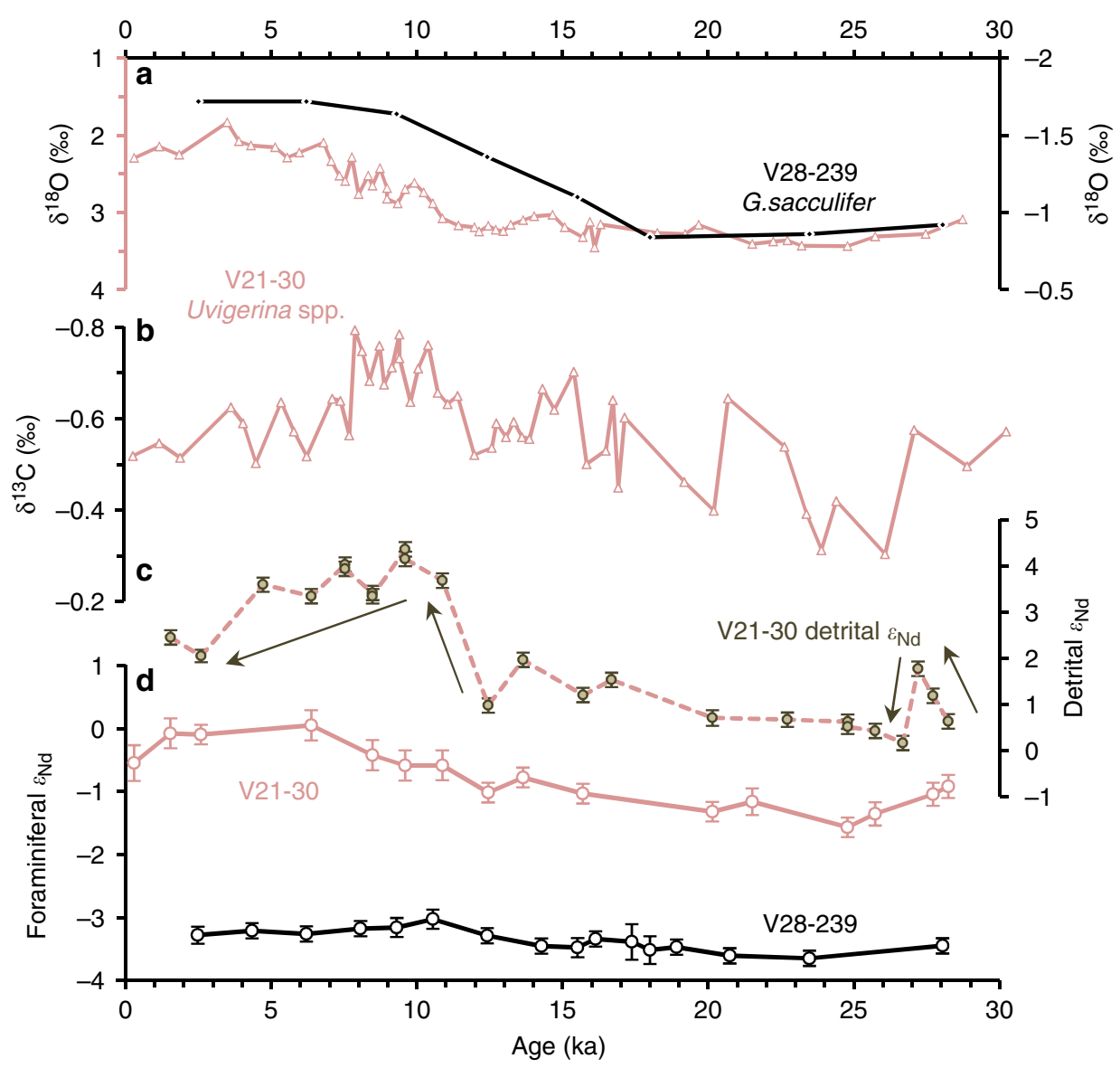

Fig. 2 Deglacial records of core V21-30 and V28-239 (0-30 ka). a Benthic $\delta^{18} \mathrm{O}$ of $\mathrm{V} 21-30$ (pink) $)^{69}$ and planktonic $\delta^{18} \mathrm{O}$ of $\mathrm{V} 28-239$ (black) ${ }^{53}$. b Benthic $\delta^{13} \mathrm{C}$ of $\mathrm{V} 21-30$ (pink) ${ }^{69}$. c Detrital $\varepsilon_{\mathrm{Nd}}$ record of $\mathrm{V} 21-30$ with arrows denoting changing trends over time. $\mathbf{d}$ Foraminiferal $\varepsilon_{\mathrm{Nd}}$ records of $\mathrm{V} 21-30$ and $\mathrm{V} 28$ 239. Error bars correspond to the $2 \sigma$ external error of the $\varepsilon_{\mathrm{Nd}}$ measurements

seawater value $(-3.4 \pm 0.4)^{24}$, while those of V21-30 $(-0.6 \pm 0.3)$ and ODP1241 $(+0.4 \pm 0.2)$ are slightly more radiogenic than ambient seawater signatures (Supplementary Table 10), probably associated with the potential dissolution of detrital fractions after deposition in the $\mathrm{EEP}^{15}$. In this case, a quantitative examination of the potential detrital contamination to porewater $\mathrm{Nd}$ isotopic signatures over time (see details in the Methods) is beneficial for reliable interpretation of the variation in foraminiferal $\varepsilon_{\mathrm{Nd}}$ records.

Our calculation shows the modelled $\varepsilon_{\mathrm{Nd}-\mathrm{pw}} \mathrm{G}-\mathrm{I}$ change from detrital contribution can explain only one third of the actual measured foraminiferal $\varepsilon_{\mathrm{Nd}} \mathrm{G}-\mathrm{I}$ change in our parameter setting (Supplementary Figs. 1, 2), which is barely analytically significant. The magnitude, timing, and direction of change in the foraminiferal $\varepsilon_{\mathrm{Nd}}$ records still cannot be produced in the $\varepsilon_{\mathrm{Nd} \text {-pw }}$ records even when we force the detrital contamination to match the core-top and LGM foraminiferal $\varepsilon_{\mathrm{Nd}}$ values (Supplementary Fig. 3). Further support for a global rather than local control on our foraminiferal $\varepsilon_{\mathrm{Nd}}$ records comes from the resemblance of our foraminiferal $\varepsilon_{\mathrm{Nd}}$ records to benthic $\delta^{18} \mathrm{O}$ (Figs. 2, 3), which is a proxy for deep water temperature and global ice volume. This would not be the case if the $\varepsilon_{\mathrm{Nd}}$ records were controlled by local sediment input. We thus suggest that the foraminiferal $\varepsilon_{\mathrm{Nd}}$ variability in our records mainly reflect evolution of bottom water $\mathrm{Nd}$ isotopes.

Recent review of seawater and archive $\varepsilon_{\mathrm{Nd}}$ values exhibits gradual latitudinal trends in the Atlantic and Pacific at depths below $600 \mathrm{~m}$, corroborating the effectiveness of $\mathrm{Nd}$ isotopes to distinguish between northern/southern sourced water contributions in the intermediate and deep waters ${ }^{12}$. The comparison of Pacific seawater $\varepsilon_{\mathrm{Nd}}$ with the conservative tracer like salinity clearly demonstrates the presence of an external $\mathrm{Nd}$ source to the Pacific which has a radiogenic composition (Fig. 4), consistent with models of the $\mathrm{Nd}$ oceanic cycle ${ }^{25,26}$. The Nd isotopic compositions of deepwater below $3 \mathrm{~km}$ are the result of adding the external radiogenic $\mathrm{Nd}$ along the LCDW advection over time. Clear local influence is limited in deep waters compared with waters above $3 \mathrm{~km}$. The increased scatter observed in $\varepsilon_{\mathrm{Nd}}$-salinity crossplot when moving from deep towards shallower waters is likely caused by the addition of external $\mathrm{Nd}$ dominantly from the upper ocean/continental margins rather than from the bottom $^{27,28}$. Another line of evidence comes from the observation of consistent $\varepsilon_{\mathrm{Nd}}$ evolution patterns and similar $\varepsilon_{\mathrm{Nd}}$ values between adjacent sites in our study. For example, the foraminiferal $\varepsilon_{\mathrm{Nd}}$ record of SO136-38 is almost identical to that of Y9 (Fig. 5b, 6b) despite the geographic distance of $>260 \mathrm{~km}$ between the two sites, because both are recording the SO AAIW at $\sim 1.3 \mathrm{~km}$ depth ${ }^{29}$. Likewise, the foraminiferal $\varepsilon_{\mathrm{Nd}}$ compositions of RC13-114 closely match those of ODP846 during the last 160 ka (Fig. 3d) although they are more than $1400 \mathrm{~km}$ apart in distance and have different $\varepsilon_{\mathrm{Nd}}$ in surrounding detrital components $^{18}$, because both cores are bathed in NPDW at $\sim 3.3-3.4 \mathrm{~km}$ depth in the EEP. Rather than showing 'exceptional disparities between adjacent sites' 28 , as would be expected from localized 


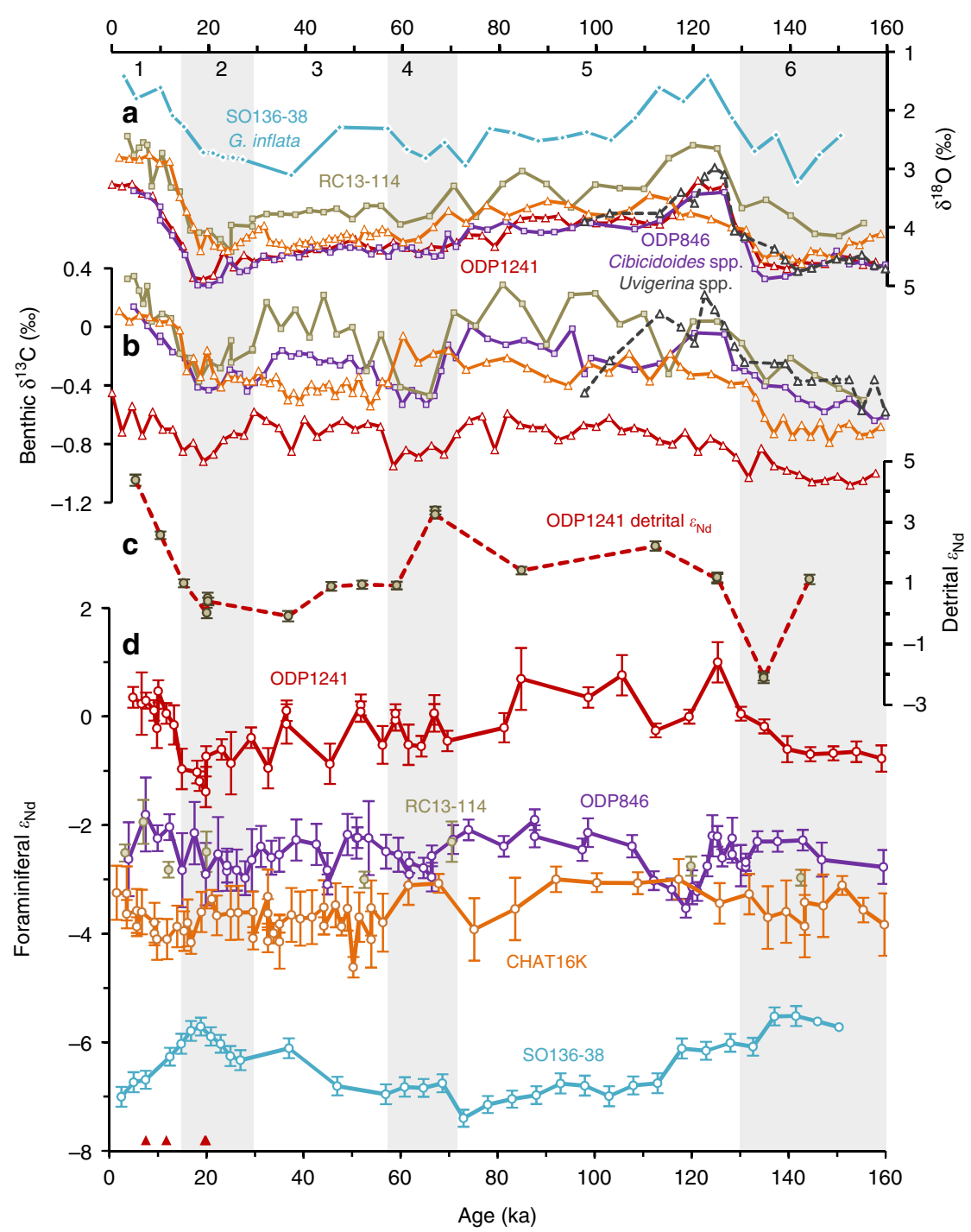

Fig. 3 Records spanning the last glacial cycle (0-160 ka). a Benthic $\delta^{18} \mathrm{O}$ and $\mathbf{b} \delta^{13} \mathrm{C}$ records of ODP1241 (red) 55 , ODP846 (purple squares for Cibicidoides spp. and grey triangles for Uvigerina spp.) ${ }^{70}, \mathrm{RC13}-114$ (brown) ${ }^{71}$, CHAT16K (orange) ${ }^{9}$ and SO136-38 (cyan) ${ }^{51}$. c Detrital $\varepsilon_{\mathrm{Nd}}$ record of ODP1241.

d Foraminiferal $\varepsilon_{\mathrm{Nd}}$ records. The red triangles beside the bottom axis represent 4 calibrated AMS ${ }^{14} \mathrm{C}$ dates of planktonic foraminiferal species $N$. dutertrei (Supplementary Table 9). Numbers on the top show MIS stages, and the grey bars highlight the glacial stages (MIS 2, 4, and 6). Error bars show the $2 \sigma$ external error of the $\varepsilon_{\mathrm{Nd}}$ measurements

sedimentary inputs, these spatial and temporal data argue against a benthic input control on the $\mathrm{Nd}$ isotopic compositions of the deep ocean and paleo-records ${ }^{27,28}$. These records show that, despite external sources of $\mathrm{Nd}$ to the Pacific, the deep water mass hydrography plays the most important role in regulating the spatial $\varepsilon_{\mathrm{Nd}}$ pattern and changes through time.

All the currently available foraminiferal $\mathrm{Nd}$ isotope records in the open Pacific which cover $0-30 \mathrm{ka}$ and $0-160 \mathrm{ka}$ are compiled in Fig. 5, 6, respectively, and unfortunately there are no such records in the open North Pacific. Except CHAT10K and CHAT16K on the northern Chatham Rise, it is clear that all the South Pacific $\varepsilon_{\mathrm{Nd}}$ records show more radiogenic $\varepsilon_{\mathrm{Nd}}$ during glacial periods (Fig. 5b, 6b), suggesting reduced contributions of North Atlantic Component Water $(\mathrm{NACW})^{30}$. Moreover, the $\varepsilon_{\mathrm{Nd}}$ values converged vertically at the G-I transitions (MIS 6/5 and MIS 2/1) in the South Pacific implying a breakdown of ocean stratification $^{6,7}$ and a larger contribution of shoaled glacial $\mathrm{NACW}^{29}$ or Ross Sea bottom water (RSBW) ${ }^{7}$ to the upper Pacific ocean. Since the glacial LCDW and SO AAIW inflow have higher
$\varepsilon_{\mathrm{Nd}}$ values than interglacials, a more radiogenic $\varepsilon_{\mathrm{Nd}}$ signature during glacial periods would be expected for the North Pacific if the glacial ocean had a circulation regime similar to the modern one ${ }^{9,11}$. However, unlike Y9 and SO136-38, the intermediatedepth core CHAT16K situated on the northern Chatham Rise saw a relatively smooth $\varepsilon_{\mathrm{Nd}}$ pattern over the past $160 \mathrm{ka}$, likely reflecting the $\varepsilon_{\mathrm{Nd}}$ signatures of Tasman AAIW which circulates around the South Pacific gyre and mixes its $\varepsilon_{\mathrm{Nd}}$ signatures with recirculating southward NPDW and possible Indonesian inputs, although a modification due to local exchange with materials from North Islands could not be excluded ${ }^{30}$. Similarly, the deeper sediment core CHAT10K located close to the North Island and outside the main flow path of the deep western boundary current probably reflects modification by local exchanges ${ }^{30}$. Therefore, it seems the cores located on the main south-to-north flowpath (i.e. in the 'S-Pac' domain of Fig. 4) in the South Pacific exhibit a similar $\varepsilon_{\mathrm{Nd}}$ evolution pattern to the Atlantic or Southern Ocean cores as a result of changing propagation of NACW, with a possible influence of RSBW. 


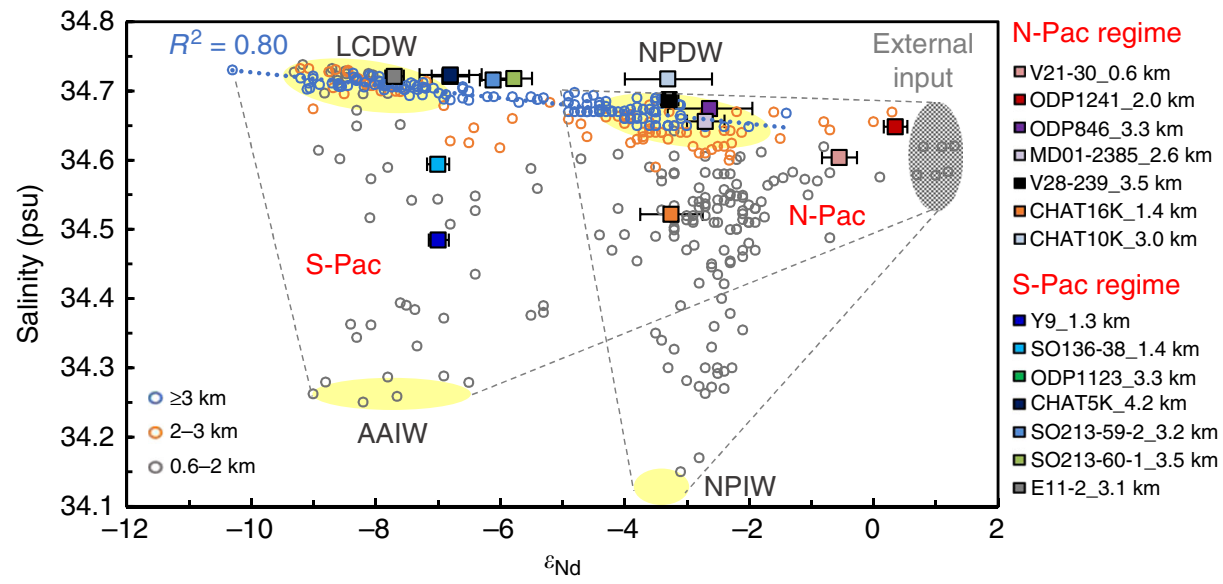

Fig. $4 \mathrm{Nd}$ isotopic data for seawater and core-top foraminifera plotted against salinity in the Pacific Ocean (>600 m). Salinity data are estimated from World Ocean Altas 2009 using location and depth of seawater $\varepsilon_{\mathrm{Nd}}$ measurements, and seawater $\varepsilon_{\mathrm{Nd}}$ data are compiled from publications (ref. ${ }^{14}$ and references within) and refs. ${ }^{16,22,24,27,72-82}$ until March 2018, excluding the unfiltered seawater of which the measured Nd isotope compositions are thought to be contaminated by particulates ${ }^{83}$. The yellow ovals show the characteristic $\varepsilon_{N d^{-}}$salinity range of the water masses ${ }^{12}$. Note that NPDW is not formed from the sinking of surface water, instead its chemical property is acquired through the ageing of LCDW. The blue dotted trend line $\left(n=136, R^{2}=\right.$ 0.8 ) exhibits a strong linear relationship between $\varepsilon_{\mathrm{Nd}}$ and salinity for deep water below $3 \mathrm{~km}$ and points to the presence of an external source with high $\varepsilon_{\mathrm{Nd}}$ compositions (grey oval). The core-top $\varepsilon_{\mathrm{Nd}}$ (see legend for sediment cores with same colour coding in this paper and the data sources in Supplementary Table 1) are plotted against ambient seawater salinity. The scatter of the data points illustrates mixing between different water masses along with additional external input of radiogenic Nd isotopes, which fall into two regions labelled by 'S-Pac' and 'N-Pac'. Except CHAT10K, all the other cores deeper than $3 \mathrm{~km}$ reside nicely on the blue dotted ageing line, providing the basis for linking the spatial $\varepsilon_{\mathrm{Nd}}$ gradients with deep water transit time. Error bars show the $2 \sigma$ external error of the $\varepsilon_{\mathrm{Nd}}$ measurements

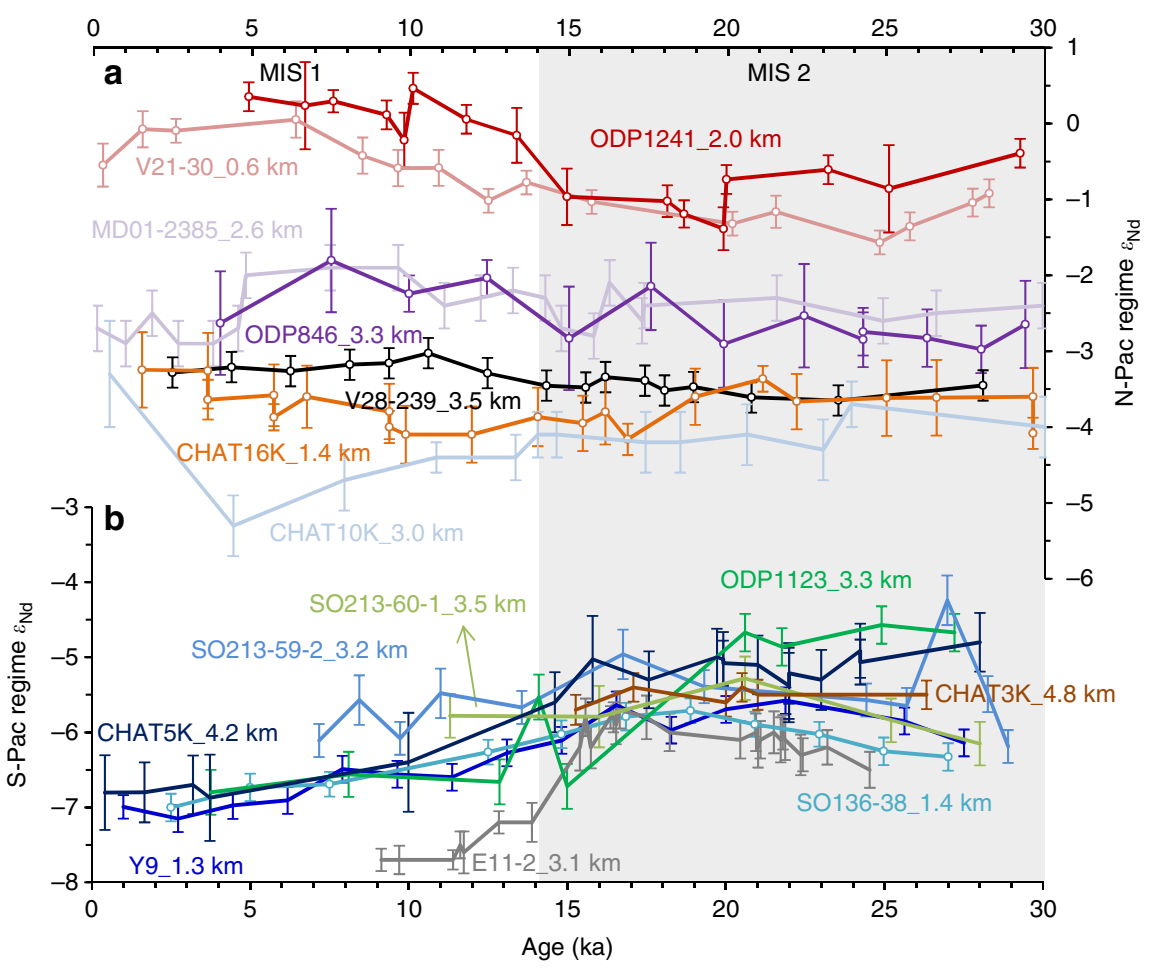

Fig. 5 A compilation of Pacific foraminiferal $\varepsilon_{N d}$ records $\left(0-30 \mathrm{ka}\right.$ ). a N-Pac regime $\varepsilon_{\mathrm{Nd}}$ patterns. b S-Pac regime $\varepsilon_{\mathrm{Nd}}$ patterns. The records with open circle symbols are measured in this study. Data sources of the other records see Supplementary Table 1. The grey bar highlights the glacial stage MIS 2. Error bars show the $2 \sigma$ external error of the $\varepsilon_{\mathrm{Nd}}$ measurements

In contrast, the higher than modern glacial $\varepsilon_{\mathrm{Nd}}$ patterns of LCDW/AAIW in the South Pacific are not transferred downstream to the North Pacific ${ }^{29}$. Instead, the cores there, along with those in the South Pacific but at shallower depths away from intense northward-flowing currents (such as CHAT10K and CHAT16K), show similar or even less radiogenic glacial $\varepsilon_{\mathrm{Nd}}$ signatures (Fig. 5a, 6a). This is not likely to be caused by the input of $\mathrm{Nd}$ from increased glacial dust with unradiogenic $\varepsilon_{\mathrm{Nd}}$, because 


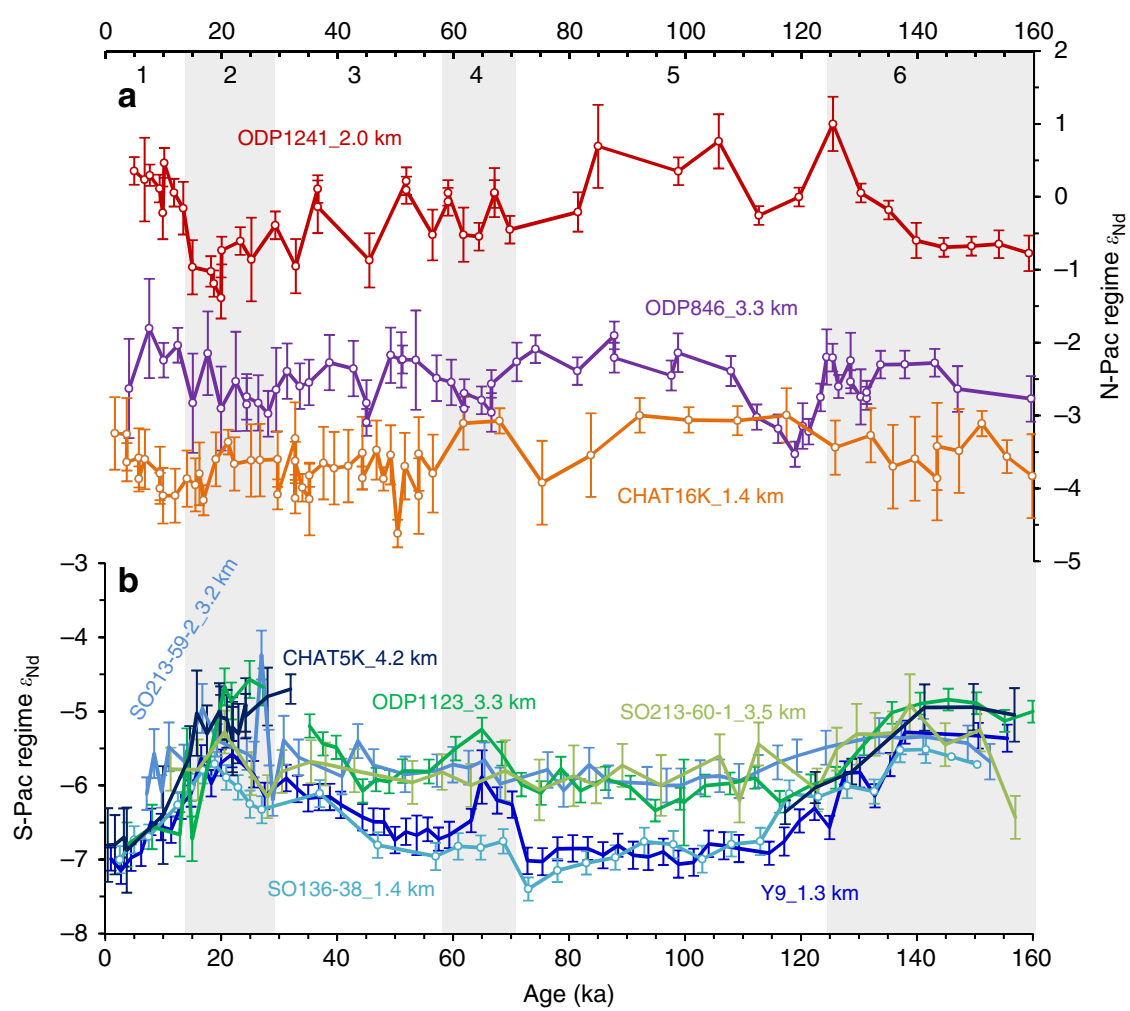

Fig. 6 A compilation of Pacific foraminiferal $\varepsilon_{N d}$ records (0-160 ka). a N-Pac regime $\varepsilon_{N d}$ patterns. b S-Pac regime $\varepsilon_{N d}$ patterns. The grey bars highlight the glacial stages (MIS 2, 4, and 6 ). Error bars show the $2 \sigma$ external error of the $\varepsilon_{\mathrm{Nd}}$ measurements

Nd budget models suggest that a 2 to 3 -fold increase in the Northern Hemisphere dust loads during the ice ages ${ }^{21}$ would not affect seawater $\varepsilon_{\mathrm{Nd}}$ in the deep Pacific Ocean ${ }^{25,31}$. Based on distinct evolution patterns, the Pacific $\varepsilon_{\mathrm{Nd}}$ records can hereby be classified into two types: 'S-Pac regime' and 'N-Pac regime'. Shallower cores in the 'N-Pac regime' (such as V21-30 and ODP1241) are prone to local modification resulting in more radiogenic $\varepsilon_{\mathrm{Nd}}$ compositions in the porewater than ambient seawater, while $\varepsilon_{\mathrm{Nd}}$ of slowly circulated deepwater is dominantly modified by the accumulation of external $\mathrm{Nd}$ input along the flowpath. The spatial $\varepsilon_{\mathrm{Nd}}$ gradients below $3 \mathrm{~km}$ can therefore be linked with deep water transit time in the Pacific.

The spatial $\varepsilon_{\mathrm{Nd}}$ gradients between South and North deep Pacific (ODP1123 and ODP846) decreased from $\sim 4-5 \varepsilon_{\mathrm{Nd}}$ units in MIS 1,3 and 5 to $\sim 2-3 \varepsilon_{\mathrm{Nd}}$ units during MIS 2, 4 and 6 (Fig. 7c), indicating a reduction in the external $\mathrm{Nd}$ input along the advection of LCDW. The diminishment of $\varepsilon_{\mathrm{Nd}}$ modification by the radiogenic external $\mathrm{Nd}$ on the northward-flowing deepwater has homogenised the spatial $\mathrm{Nd}$ isotope signatures during the glacial times. Weathering of continental margins and volcanic islands/arcs in the 'Ring of Fire' surrounding the Pacific Ocean supplies the external source of radiogenic $\mathrm{Nd}$ to the deep water through boundary exchange ${ }^{32}$ or particle dissolution ${ }^{33}$. Changes in its weathering rate through time are thought to affect the external Nd flux into the ocean. During glacial periods, chemical weathering rate of oceanic islands under colder conditions (assuming average $1.7 \pm 1{ }^{\circ} \mathrm{C}$ cooling for the global surface ocean during the $\mathrm{LGM}^{34}$ ) would be expected to be slightly decreased $(\sim 4-15 \%)^{35}$, while this could be partly balanced by small increase in cation weathering flux by enhanced exposure of island area available for weathering ${ }^{36}$. The counteracting effect thus likely results in negligible G-I variation in continental chemical weathering rates ${ }^{36,37}$. Rather, our data are more consistent with faster Pacific overturning circulation reducing the spatial $\varepsilon_{\mathrm{Nd}}$ gradients during the glacial periods.

To carry out a quantitative estimation of changes in the deep Pacific transit time in the past, a box model is developed here (see details in the Methods). Our study provides a first crude estimation for the deep Pacific transit time, which varied between 350 and 1200 years over the last $160 \mathrm{ka}$ (Fig. 7d). The averaged deepwater transit time at late Holocene $(4-5 \mathrm{ka})$ is $~ 950 \pm 130$ years, in agreement with the modern tracer observation 38,39 . The deep Pacific transit time in glacial times (MIS 2,4 and 6) was systematically shorter compared to interglacials (MIS 1, 3 and 5), with fastest circulation during peak glacial periods. Deep water $\delta^{13} \mathrm{C}$ has been traditionally regarded as a ventilation tracer, and the spatial gradients have shed light on water mass ageing. When LCDW travels across the Pacific, it progressively accumulates nutrients and depleted $\delta^{13} \mathrm{C}$ through the remineralization of sinking organic matter, as well as mixing with the overlying waters. The similarity between the $\Delta \delta^{13} C_{846-1123}$ and our $\Delta \varepsilon_{\mathrm{Nd} 846-1123}$ records (Fig. 7) lends support for our interpretation on the deepwater circulation rates in the Pacific. This interpretation is also supported by sortable silt evidence of ODP1123 in the SWP ${ }^{8}$, but interestingly conflicts with bulk leachate $\varepsilon_{\mathrm{Nd}}$ records located along formerly glaciated active volcanic margins in the Gulf of Alaska ${ }^{10}$, a geological environment where local detrital control has been substantiated ${ }^{28,40}$. Although there are uncertainties in our simplified model, sensitivity tests show that the pattern of faster Pacific overturning circulation during glacial stages is still maintained over the last $160 \mathrm{ka}$ (Supplementary Fig. 4).

The hypothetical Pacific overturning circulation states during the interglacial and glacial stages are synthesized in Fig. 8. 


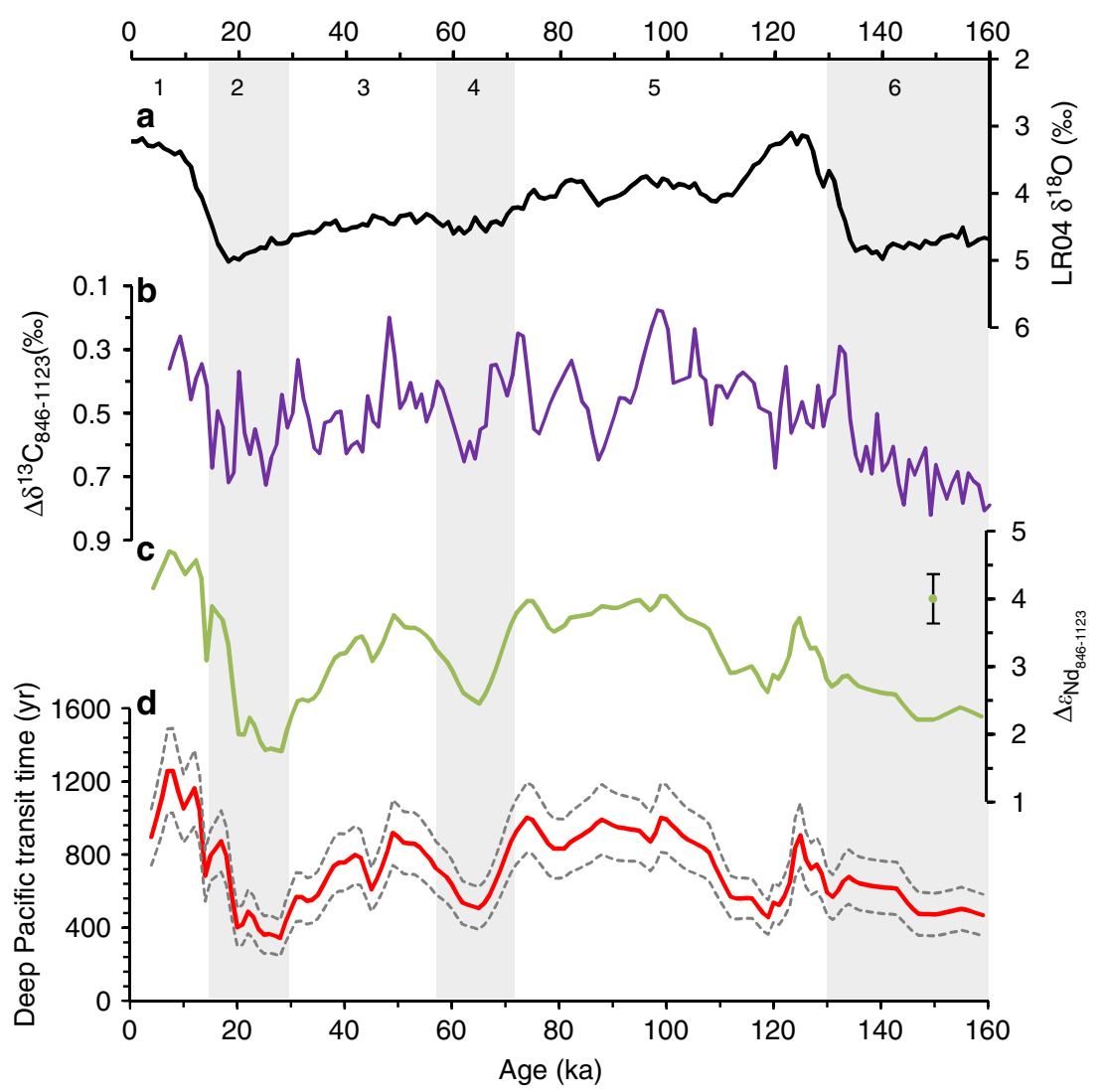

Fig. 7 Deep Pacific transit time over the last $160 \mathrm{ka}$. a Benthic $\delta^{18} \mathrm{O}$ stack ${ }^{50}$. b Benthic $\delta^{13} \mathrm{C}$ gradients between ODP846 and ODP1123. Note that the benthic $\delta^{13} \mathrm{C}$ of ODP846 (C. wuellerstorfi) ${ }^{70}$ and ODP1123 (Uvigerina spp.) $)^{8}$ are measured on different species and vital effects might affect their $\delta^{13} \mathrm{C}$ signatures. c Foraminiferal $\varepsilon_{\mathrm{Nd}}$ gradients between ODP846 and ODP1123. d The deep Pacific transit time estimated from the box model (see parameters in Supplementary Table 10). The grey dash lines display uncertainties propagated from $\varepsilon_{\mathrm{Nd}}$ measurements (averaged $2 \sigma$ for ODP1123 and ODP846 are 0.19 and 0.31 , respectively) into the transit time. The grey bars highlight the glacial stages (MIS 2, 4 and 6)
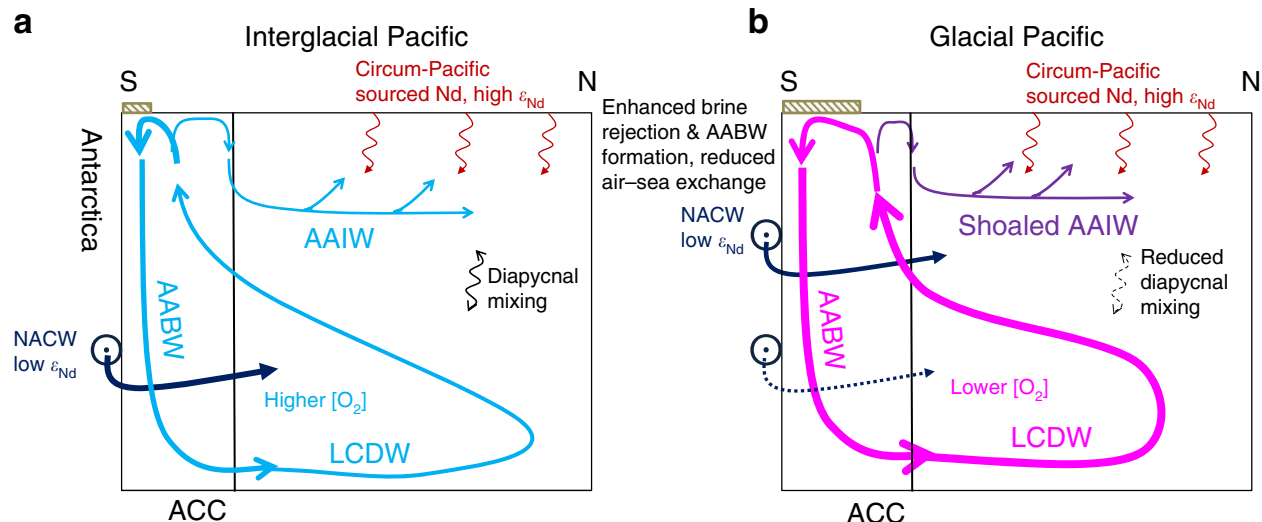

Fig. 8 The Pacific overturning schematics during the G-I states. a Interglacial sketch. b Glacial sketch. The vertical black line bounds the northernmost extension of the ACC. Line colours from dark blue, light blue to purple, pink and red indicate increasing $\varepsilon_{\mathrm{Nd}}$ values: dark blue North Atlantic Component Water (NACW) with low $\varepsilon_{\mathrm{Nd}}$ values, red circum-Pacific $\mathrm{Nd}$ sources with radiogenic $\varepsilon_{\mathrm{Nd}}$ values. Line thickness changes among panels denote changes in flow flux/rate. The red wavy arrows show the addition of circum-Pacific Nd sources with radiogenic $\varepsilon_{N d}$ values from the upper ocean to the deep ocean. The black wavy arrows show the diapycnal mixing between different depths. Today, the Atlantic component water with low $\varepsilon_{\mathrm{Nd}}$ compositions is propagated into the deep Southern Ocean and incorporated into the LCDW via the ACC. During the glacial periods, with the build-up of sea-ice and enhanced brine rejection, the formation rate of $A A B W$ may have increased

Compared with the interglacial state, a faster Pacific overturning circulation is inferred during glacial times, probably driven by enhanced formation and export of $\mathrm{AABW}^{8,41}$ and/or a northward expansion of $\mathrm{RSBW}^{7}$ into the Pacific due to increased sea-ice production and brine rejection ${ }^{42,43}$. The $\mathrm{Nd}$ isotopes from S-Pac regimes also support a reduced water mass mixing between 
LCDW and AAIW during glacials ${ }^{29}$, likely associated with reduced diapycnal mixing in a more stratified ocean ${ }^{44}$. The shoaling of NADW in the North Atlantic would lead to more NACW restricted to the upper cell which made their way to the Pacific basin via the eastward flowing ACC. Based on benthic carbon isotopes and radiocarbon evidence, the water mass geometry in the glacial South Pacific was not greatly different to the modern state ${ }^{6,9}$. The water mass boundary between the LCDW and UCDW/NPDW remained at $\sim 3.5 \mathrm{~km}$, while the lower boundary of AAIW may have been slightly shoaled to $1.2 \mathrm{~km}^{45}$. The potential increased carbon stock in the deep Pacific inferred from low oxygenated deep water ${ }^{2,46}$ would probably not be related to reduced circulation strength, but rather indicating lower oxygen concentration in the Southern Ocean ${ }^{46,47}$, in accordance with depleted radiocarbon observations $s^{3,48}$. We conclude that a faster but less ventilated overturning circulation might have operated in the glacial Pacific Ocean, and mechanisms such as increased biological pump efficiency and poor high latitude air-sea exchange ${ }^{49}$ may be responsible for atmospheric $\mathrm{CO}_{2}$ drawdown in the deep Pacific Ocean during glacial periods. Our results here thus put constraints on ocean circulation models to better simulate the atmospheric $\mathrm{CO}_{2}$ change through past G-I cycles.

\section{Methods}

Sediment cores. Foraminiferal Nd isotopes are measured on seven new cores in this study, including two from the SWP, one from the WEP and four from the EEP.

CHAT16K and SO136-38 (at $\sim 1.4 \mathrm{~km}$ water depth) are located to the north and south of the Chatham Rise, recording the signatures of two different AAIW types, i.e. Tasman AAIW and SO AAIW (also termed as AAIW $_{\mathrm{N}}$ and AAIW $_{\mathrm{s}}{ }^{9}$ ), respectively (Fig. 1a). The age model of the northern site CHAT16K is slightly modified by retuning the Uvigerina peregrine $\delta^{18} \mathrm{O}$ record ${ }^{9}$ to LR04 stack ${ }^{50}$. New $\varepsilon_{\mathrm{Nd}}$ measurements on CHAT16K is performed, extending the existing deglacial record $^{30}$ to $160 \mathrm{ka}$. The age model of the southern site SO136-38 is constructed by correlating $\delta^{18} \mathrm{O}$ profile of Globorotalia inflata ${ }^{51}$ to a new global planktonic $\delta^{18} \mathrm{O}$ $\operatorname{stack}^{52}$.

The western equatorial core V28-239 was raised from the Solomon Plateau at a water depth of $3490 \mathrm{~m}$. The age model is developed by tuning Globigerinoides sacculifer $\delta^{18} \mathrm{O}$ record ${ }^{53}$ to the planktonic $\delta^{18} \mathrm{O}$ stack $^{52}$.

Four sediment cores in the EEP were taken from water depth between 617 and $3436 \mathrm{~m}$, with foraminiferal $\mathrm{Nd}$ isotopes analysed on all the cores and detrital $\mathrm{Nd}$ isotopes on two sites (ODP1241 and V21-30). The shallowest core V21-30 is situated in the modern oxygen minimum zone, with an average sedimentation rate of $13 \mathrm{~cm} \mathrm{ka}^{-1}$ over the past $30 \mathrm{ka}$ based on radiocarbon age $\mathrm{e}^{54}$. The age model of ODP $1241^{55}$ is modified by measuring 4 new ${ }^{14} \mathrm{C}$ dates (Neogloboquadrina dutertrei $>300 \mu \mathrm{m}$ ) for the upper $60 \mathrm{~cm}$ of Hole B (Supplementary Table 9). Deeper cores ODP846 and RC13-114 are bathed at similar water depths $(\sim 3.3-3.4$ $\mathrm{km}$ ), and their foraminiferal $\varepsilon_{\mathrm{Nd}}$ compositions are compared to check the reliability of this archive in recording water mass $\varepsilon_{\mathrm{Nd}}$ signatures.

Nd isotope measurements. Nd isotopes are measured on both foraminifera (for all the seven cores) and detrital fraction of the bulk sediments (for EEP cores V2130 and ODP 1241). The former is used to trace the porewater $\mathrm{Nd}$ isotope changes, whereas the latter is used to identify changes in provenance and inputs of lithogenic materials.

Foraminifera for each sample were prepared following a routine protocol ${ }^{13}$. In brief, 30-100 mg planktonic foraminifera of each sample were handpicked from $>63 \mu \mathrm{m}$ fraction. All clays were removed by ultrasonication after the foraminiferal tests were broken open. The physically cleaned foraminifera were then dissolved in $1 \mathrm{M}$ acetic acid.

For detrital analysis, 3-5 g sediment was repeatedly decarbonated overnight using a buffered acetic acid solution until the lack of $\mathrm{CO}_{2}$ production indicating no carbonate remained. Then the decarbonated samples were MilliQ water rinsed and leached twice with a $0.02 \mathrm{M}$ solution of hydroxylamine hydrochloride in $25 \%(\mathrm{v} / \mathrm{v})$ acetic acid. The residues were then MilliQ rinsed, dried and soaked in $10 \%$ peroxide to remove organic matter. After drying down again, the detrital samples were sequentially digested by the mixture of concentrated $\mathrm{HNO}_{3}$ and $\mathrm{HF}$ for at least $48 \mathrm{~h}$ at $110^{\circ} \mathrm{C}$ and by aqua regia for another $24 \mathrm{~h}$ at $80^{\circ} \mathrm{C}$.

After dissolution, all samples underwent a two-step ion chromatographic separation (Eichrom TRUspec and Eichrom LNspec resin) to isolate and purify Nd. The isotopic ratios of $\mathrm{Nd}$ were analysed on a Nu Plasma or Thermo Neptune Plus multi-collector inductively-coupled plasma mass spectrometer (MC-ICP-MS) in the Department of Earth Sciences at the University of Cambridge. Procedural blanks for foraminiferal and detrital samples were negligible (less than $0.3 \%$ and $0.07 \%$, respectively) and were therefore not corrected for. Instrumental mass bias was corrected by applying an exponential mass fractionation law using ${ }^{146} \mathrm{Nd}$ /

${ }^{144} \mathrm{Nd}$ of 0.7219 and each sample was bracketed with the concentration-matched reference standard JNdi-1, the measured composition of which was corrected to the accepted value of ${ }^{143} \mathrm{Nd} /{ }^{144} \mathrm{Nd}=0.512115$. The external reproducibilities $(2 \sigma)$ of $\mathrm{Nd}$ isotope measurement during each analytical session are given by repeated measurements on concentration-matched JNdi-1 standards. The average $2 \sigma$ external reproducibility for $20 \mathrm{ng}$ of $\mathrm{Nd}$ is $\sim 0.2$ (on Neptune Plus) and $\sim 0.5$ (on $\mathrm{Nu}$ Plasma) $\varepsilon_{\mathrm{Nd}}$ units, while larger errors for some samples reflect low $\mathrm{Nd}$ abundance due to small sample sizes.

Examination of detrital influence on porewater $\varepsilon_{\mathbf{N d}}$ records. The influence of detrital dissolution to porewater $\varepsilon_{\mathrm{Nd}}$ for V21-30 and ODP1241 over the studied periods is estimated via a binary mixing model: the $\varepsilon_{\mathrm{Nd}}$ of the sedimentary porewater $\left(\varepsilon_{\mathrm{Nd}-\mathrm{pw}}\right)$ is determined by a mixing of seawater derived $\mathrm{Nd}$ (authigenic) and lithogenic particulate $\mathrm{Nd}$ (old continental and young volcanic arc material). The relationship is expressed as follows:

$$
\varepsilon_{\mathrm{Nd}-\mathrm{pw}}=\frac{\varepsilon_{\mathrm{Nd}-\mathrm{au}} \times F_{\mathrm{au}}+\varepsilon_{\mathrm{Nd}-\mathrm{vol}} \times \alpha_{\mathrm{vol}} F_{\mathrm{vol}}+\varepsilon_{\mathrm{Nd}-\mathrm{cont}} \times \alpha_{\mathrm{cont}} F_{\mathrm{cont}}}{F_{\mathrm{au}}+\alpha_{\mathrm{vol}} F_{\mathrm{vol}}+\alpha_{\mathrm{cont}} F_{\text {cont }}}
$$

All the parameters and their values used in this model are shown in Supplementary Table 10. In fact, modern oceanic Nd isotope budget has been constrained in many previous studies ${ }^{25,56}$, which allows us to estimate the authigenic Nd flux $\left(F_{\mathrm{au}}\right)$ to the sea floor. A mean authigenic Nd flux in the Pacific Ocean $\left(F_{\text {mean }}\right)$ is calculated based on Nd residence time $(\tau=\sim 500 \mathrm{yr})^{25}$ as follows:

$$
\tau=\frac{C_{\mathrm{d}} \times \rho V \times M_{\mathrm{Nd}}}{F_{\text {mean }} \times \mathrm{A}}
$$

Using the parameters in Supplementary Table 10, we obtain a mean authigenic Nd flux $\left(F_{\text {mean }}\right)$ in the Pacific of $\sim 2.76 \times 10^{-5} \mathrm{~g} \mathrm{~m}^{-2} \mathrm{yr}^{-1}$. This number is in agreement with previous INDOPAC box estimation using 10-box model ${ }^{25}$. Settling particles are considered to be the main flux of particulate material to the seafloor. The authigenic Nd flux thus varies with different particle fluxes, resulting in higher flux in the marginal region and much lower flux in the pelagic central Pacific region ${ }^{56}$. The adopted $F_{\text {mean }}$ should be taken as the lower limit of authigenic flux for our EEP cores and thus is a conservative estimation.

Given a rich carbonate $(\sim 60-80 \%)$ and low diatom contents $(<10 \%)$ of V21-30 and ODP1241 in our studied intervals ${ }^{17,57}$, the lithogenic Nd flux $\left(F_{\text {litho }}\right)$ composed is taken as the non-carbonate sedimentary flux when a detrital $\mathrm{Nd}$ concentration $\left(C_{\mathrm{p}}\right)$ is applied:

$$
F_{\text {litho }}=\mathrm{DBD} \times \mathrm{LSR} \times\left(1-X_{\mathrm{CaCO} 3}\right) \times C_{\mathrm{p}}
$$

Linear sediment rate (LSR) is calculated based on the age model. Constant dry bulk density $\left(\mathrm{DBD}=0.63 \mathrm{~g} \mathrm{~cm}^{-3}\right)$, low-resolution $\mathrm{CaCO}_{3} \%$ data points of ODP1241 are from the initial IODP report $(\sim 60-70 \%)^{17}$, and the rest $\mathrm{CaCO}_{3} \%$ are extrapolated based on exponential relationship with measured coarse fraction $\% 55$. The shallower core V21-30 has high $\mathrm{CaCO}_{3} \%$, and the contents of MIS 1 and MIS 2 are represented by the measurements of core-top $=70 \%{ }^{58}$ and $\mathrm{LGM}=77 \%{ }^{59}$, respectively. The core-top and LGM Nd concentrations for the detritus of ODP1241 $\left(C_{\mathrm{p}}\right)$ we measured are very similar (15.0 and $14.8 \mathrm{ppm}$, respectively), and thus a constant value of $15 \mathrm{ppm}$ is taken for both cores for simplicity.

The lithogenic detrital Nd flux is composed of continental flux $\left(F_{\text {cont }}\right)$ and volcanic flux $\left(F_{\mathrm{vol}}\right)$

$$
F_{\text {litho }}=F_{\text {vol }}+F_{\text {cont }}
$$

The proportions of old continental particles $\left(X_{\text {cont }}\right)$ and volcanic $\left(1-X_{\text {cont }}\right)$ components over time can be further calculated based on a two-endmember mixing model: the detrital $\varepsilon_{\mathrm{Nd}}$ is determined by a mixing of $\mathrm{Nd}$ from old continental particles (average $\left.\varepsilon_{\mathrm{Nd} \text {-cont }}=-10\right)^{23}$ and Central America/Galapagos volcanic arcs (average $\left.\varepsilon_{\mathrm{Nd} \text {-vol }}=+7\right)^{22}$ as follows:

$$
\begin{gathered}
\varepsilon_{\mathrm{Nd}-\mathrm{d}}=\varepsilon_{\mathrm{Nd}-\text { cont }} \times X_{\text {cont }}+\varepsilon_{\mathrm{Nd}-\mathrm{vol}} \times\left(1-X_{\text {cont }}\right) \\
F_{\text {cont }}=F_{\text {litho }} \times X_{\text {cont }}
\end{gathered}
$$

The Nd dissolution factors $(\alpha)$ of the corresponding components are assumed to be constant with respect to time $\mathrm{e}^{25}$. The proportion of soluble $\mathrm{Nd}$ in marine particles is thought to be highly variable $60-63$, but literature suggests that the basaltic material is usually more reactive compared to continental/granitic material ${ }^{64}$ and has been replicated in closed-system experiments ${ }^{65}$. $\alpha_{\text {cont }}=2 \%$ 
derived from laboratory experiment ${ }^{60}$ is commonly used in $\mathrm{Nd}$ budget calculations ${ }^{26,56,66}$, while there is no common $\alpha_{\mathrm{vol}}$ so far in the literature, ranged from $<0.4 \%^{67}$ to $\sim 1.5-8.5 \%{ }^{68}$ based on batch reactor experiments.

We have taken approach that first making the core-top $\varepsilon_{\text {Nd-pw }}$ value match the measured foraminiferal $\varepsilon_{\mathrm{Nd}}$ in Eq. (1). Assuming a constant authigenic $\mathrm{Nd}$ flux $\left(F_{\text {au }}=F_{\text {mean }}=2.76 \times 10^{-5} \mathrm{~g} \mathrm{~m}^{-2} \mathrm{yr}^{-1}\right)$, we obtain $\alpha_{\text {arc }}=3 \%$ for V21-30 and $\alpha_{\text {arc }}=$ $9 \%$ for ODP1241, both of which are within the range of reported marine particle dissolution factors. This means the discrepancy between the seawater and core-top foraminiferal $\varepsilon_{\mathrm{Nd}}$ for our EEP cores could be explained by detrital contamination of $2 \%$ continental particle dissolution and 3-9\% volcanic material dissolution during diagenesis after burial. The parameters are then applied back in time to derive the $\varepsilon_{\mathrm{Nd}-\mathrm{pw}}$ records of both cores in Figs. 1c, 2c.

Considering the uncertainties of the parameters such as the true authigenic $\mathrm{Nd}$ flux $\left(F_{\mathrm{au}}\right)$ and the wide range of dissolution factors of volcanic and continental materials $\left(\alpha_{\text {vol }}\right.$ and $\left.\alpha_{\text {cont }}\right)$, a sensitivity test is performed by creating the same G-I change in porewater $\varepsilon_{\mathrm{Nd}}$ records artificially to see how the $\varepsilon_{\mathrm{Nd}-\mathrm{pw}}$ calculated compared to our measured foraminiferal $\varepsilon_{\mathrm{Nd}}$ through time (Supplementary Fig. 3).

Box model for estimating deep Pacific transit time. In this model, the deep Pacific Ocean is treated as a box with LCDW exclusively ventilated from the Southern Ocean, and the water mass $\varepsilon_{\mathrm{Nd}}$ signatures are assumed to be gradually modified in the process of northward LCDW advection by time-dependant accumulation of external $\mathrm{Nd}$ input from a constant source ${ }^{15}$. To carry out such work the basic principle for selecting the tracer is that it could have a residence time comparable to the oceanic transit time, i.e. a few hundred years. In the upper, ocean $\mathrm{Nd}$ isotopes is actively recycled by particles ${ }^{62,63}$, which will lead to short residence time. In this regard, ODP1123 and ODP846 are chosen to calculate the deep transit time from the northward-flowing LCDW in the SWP to the southerly return flow in the EEP as regional/local influence on Nd isotope compositions for deep water below $3 \mathrm{~km}$ and away from continental margins should be limited ${ }^{28,33}$. Assuming steady state, the scavenged $\mathrm{Nd}$ has the same isotope composition as in-situ seawater and the concentration of $\mathrm{Nd}\left(Q_{\mathrm{Nd}}\right)$ equals to the sum of $\mathrm{Nd}$ brought by the LCDW inflow ( $Q_{\mathrm{LCDW}}$, which is supposed to be constant over time) and the accumulation of external input over transit time $(t)$. The reference flux of external input $\left(f_{\mathrm{EI}}=\right.$ $3.24 \times 10^{9} \mathrm{~g} \mathrm{yr}^{-1}$ ) is averaged from previous model estimations for the Pacific Ocean $^{25,66}$, and the reference $\varepsilon_{\mathrm{Nd}}$ value of external input $\left(\varepsilon_{\mathrm{Nd}-\mathrm{EI}}=+1\right)$ is adopted from earlier model of oceanic Nd budget ${ }^{25}$. The $\varepsilon_{\mathrm{Nd}}$ of the deep water along the pathway over time can thus be calculated by the mass and isotope balance as follows:

$$
\varepsilon_{\mathrm{Nd}-\mathrm{LCDW}} \times Q_{\mathrm{LCDW}}+\varepsilon_{\mathrm{Nd}-\mathrm{EI}} \times f_{\mathrm{EI}} \times t=\varepsilon_{\mathrm{Nd}} \times\left(Q_{\mathrm{LCDW}}+f_{\mathrm{EI}} \times t\right)
$$

All the parameters and their values used in this model are shown in Supplementary Table 10. The reliability of our calculation based on this equation is supported by the ability to reproduce modern deepwater $\varepsilon_{\mathrm{Nd}}$ distribution ${ }^{12}$.

Considering the uncertainties and the potential variability of the external $\mathrm{Nd}$ input into the deep ocean over time, sensitivity tests have been performed varying $\varepsilon_{\mathrm{Nd}-\mathrm{EI}}=0,+0.5,+1,+1.5,+2$ and $f_{\mathrm{EI}}=2.84,3,3.24,3.4,3.63 \times 10^{9} \mathrm{~g} \mathrm{yr}^{-1}$, respectively, for reconstructing the deep Pacific transit time during the last $160 \mathrm{ka}$ (Supplementary Fig. 4).

\section{Data availability}

The data reported in this paper are provided in the Supplementary Information.

Received: 12 April 2018 Accepted: 10 October 2018

Published online: 09 November 2018

\section{References}

1. Bradtmiller, L. I., Anderson, R. F., Sachs, J. P. \& Fleisher, M. Q. A deeper respired carbon pool in the glacial equatorial Pacific Ocean. Earth Planet. Sci. Lett. 299, 417-425 (2010).

2. Jaccard, S. L. \& Galbraith, E. D. Large climate-driven changes of oceanic oxygen concentrations during the last deglaciation. Nat. Geosci. 5, 151-156 (2012).

3. Skinner, L. et al. Reduced ventilation and enhanced magnitude of the deep Pacific carbon pool during the last glacial period. Earth Planet. Sci. Lett. 411, 45-52 (2015).

4. Freeman, E., Skinner, L. C., Waelbroeck, C. \& Hodell, D. Radiocarbon evidence for enhanced respired carbon storage in the Atlantic at the Last Glacial Maximum. Nat. Commun. 7, 11998 (2016).

5. Gebbie, G. How much did Glacial North Atlantic Water shoal? Paleoceanography 29, 190-209 (2014).

6. Ronge, T. A. et al. Radiocarbon constraints on the extent and evolution of the South Pacific glacial carbon pool. Nat. Commun. 7, 11487 (2016).
7. Basak, C. et al. Breakup of last glacial deep stratification in the South Pacific. Science 359, 900-904 (2018).

8. Hall, I. R., McCave, I. N., Shackleton, N. J., Weedon, G. P. \& Harris, S. E. Intensified deep Pacific inflow and ventilation in Pleistocene glacial times. Nature 412, 809-812 (2001).

9. McCave, I. N., Carter, L. \& Hall, I. R. Glacial-interglacial changes in water mass structure and flow in the SW Pacific Ocean. Quat. Sci. Rev. 27, 1886-1908 (2008).

10. $\mathrm{Du}$, J. et al. Flushing of the deep Pacific Ocean and the deglacial rise of atmospheric $\mathrm{CO}_{2}$ concentrations. Nature Geoscience 11, 749-755 (2018).

11. Matsumoto, K. \& Lynch-Stieglitz, J. Similar glacial and Holocene deep water circulation inferred from southeast Pacific benthic foraminiferal carbon isotope composition. Paleoceanography 14, 149-163 (1999).

12. Tachikawa, K. et al. The large-scale evolution of neodymium isotopic composition in the global modern and Holocene ocean revealed from seawater and archive data. Chem. Geol. 457, 131-148 (2017).

13. Roberts, N. L., Piotrowski, A. M., McManus, J. F. \& Keigwin, L. D. Synchronous deglacial overturning and water mass source changes. Science 327, 75-78 (2010).

14. Lacan, F., Tachikawa, K. \& Jeandel, C. Neodymium isotopic composition of the oceans: a compilation of seawater data. Chem. Geol. 300-301, 177-184 (2012).

15. Hu, R., Piotrowski, A. M., Bostock, H. C., Crowhurst, S. \& Rennie, V. Variability of neodymium isotopes associated with planktonic foraminifera in the Pacific Ocean during the Holocene and Last Glacial Maximum. Earth Planet. Sci. Lett. 447, 130-138 (2016).

16. Grasse, P. et al. Short-term variability of dissolved rare earth elements and neodymium isotopes in the entire water column of the Panama Basin. Earth Planet. Sci. Lett. 475, 242-253 (2017).

17. Mix, A. C., Tiedemann, R., Baldauf, J. \& Blum, P. Site 1241. In Proc. Ocean Drill. Program, Initial Report Vol. 202, Ch. 12 (ODP, 2003).

18. Xie, R. C. \& Marcantonio, F. Deglacial dust provenance changes in the Eastern Equatorial Pacific and implications for ITCZ movement. Earth Planet. Sci. Lett. 317-318, 386-395 (2012).

19. Reimi, M. A. \& Marcantonio, F. Constraints on the magnitude of the deglacial migration of the ITCZ in the Central Equatorial Pacific Ocean. Earth Planet. Sci. Lett. 453, 1-8 (2016).

20. Jiang, F. et al. Asian dust input in the western Philippine Sea: Evidence from radiogenic Sr and Nd isotopes. Geochem. Geophys. Geosystems 14, 1538-1551 (2013).

21. Winckler, G., Anderson, R. F., Fleisher, M. Q., McGee, D. \& Mahowald, N. Covariant glacial-interglacial dust fluxes in the Equatorial Pacific and Antarctica. Science 320, 93-96 (2008).

22. Grenier, M. et al. From the subtropics to the central equatorial Pacific Ocean: Neodymium isotopic composition and rare earth element concentration variations. J. Geophys. Res. Oceans 118, 592-618 (2013).

23. Nakai, Si, Halliday, A. N. \& Rea, D. K. Provenance of dust in the Pacific Ocean. Earth Planet. Sci. Lett. 119, 143-157 (1993).

24. Behrens, M. K., Pahnke, K., Schnetger, B. \& Brumsack, H.-J. Sources and processes affecting the distribution of dissolved $\mathrm{Nd}$ isotopes and concentrations in the West Pacific. Geochim. Cosmochim. Acta 222, 508-534 (2018).

25. Tachikawa, K., Athias, V. \& Jeandel, C. Neodymium budget in the modern ocean and paleo-oceanographic implications. J. Geophys. Res. 108, 3254 (2003).

26. Rempfer, J., Stocker, T. F., Joos, F., Dutay, J.-C. \& Siddall, M. Modelling Ndisotopes with a coarse resolution ocean circulation model: Sensitivities to model parameters and source/sink distributions. Geochim. Cosmochim. Acta 75, 5927-5950 (2011).

27. Abbott, A. N., Haley, B. A. \& McManus, J. Bottoms up: sedimentary control of the deep North Pacific Ocean's $\varepsilon_{\text {Nd }}$ signature. Geology 43, 1035 (2015).

28. Haley, B. A., Du, J., Abbott, A. N. \& McManus, J. The impact of benthic processes on rare Earth element and neodymium isotope distributions in the oceans. Front. Marine Sci. 4, https://doi.org/10.3389/fmars.2017.00426 (2017).

29. Hu, R. et al. Neodymium isotopic evidence for linked changes in Southeast Atlantic and Southwest Pacific circulation over the last 200 kyr. Earth Planet. Sci. Lett. 455, 106-114 (2016).

30. Noble, T. L., Piotrowski, A. M. \& McCave, I. N. Neodymium isotopic composition of intermediate and deep waters in the glacial southwest Pacific. Earth Planet. Sc. Lett. 384, 27-36 (2013).

31. Rempfer, J., Stocker, T. F., Joos, F. \& Dutay, J.-C. Sensitivity of Nd isotopic composition in seawater to changes in $\mathrm{Nd}$ sources and paleoceanographic implications. J. Geophys. Res. 117, C12010 (2012).

32. Lacan, F. \& Jeandel, C. Neodymium isotopes as a new tool for quantifying exchange fluxes at the continent-ocean interface. Earth Planet. Sci. Lett. 232, 245-257 (2005)

33. Jeandel, C. \& Oelkers, E. H. The influence of terrigenous particulate material dissolution on ocean chemistry and global element cycles. Chem. Geol. 395, 50-66 (2015). 
34. MARGO Project Members. Constraints on the magnitude and patterns of ocean cooling at the Last Glacial Maximum. Nat. Geosci. 2, 127-132 (2009).

35. Li, G. et al. Temperature dependence of basalt weathering. Earth Planet. Sci. Lett. 443, 59-69 (2016).

36. Foster, G. L. \& Vance, D. Negligible glacial-interglacial variation in continental chemical weathering rates. Nature 444, 918-921 (2006).

37. von Blanckenburg, F., Bouchez, J., Ibarra, D. E. \& Maher, K. Stable runoff and weathering fluxes into the oceans over Quaternary climate cycles. Nat. Geosci. 8, 538 (2015).

38. Khatiwala, S., Primeau, F. \& Holzer, M. Ventilation of the deep ocean constrained with tracer observations and implications for radiocarbon estimates of ideal mean age. Earth Planet. Sci. Lett. 325-326, 116-125 (2012).

39. Matsumoto, K. Radiocarbon-based circulation age of the world oceans. J. Geophys. Res. Oceans 112, C09004 (2007).

40. Du, J., Haley, B. A. \& Mix, A. C. Neodymium isotopes in authigenic phases, bottom waters and detrital sediments in the Gulf of Alaska and their implications for paleo-circulation reconstruction. Geochim. Cosmochim. Acta 193, 14-35 (2016).

41. Fichefet, T., Hovine, S. \& Duplessy, J.-C. A model study of the Atlantic thermohaline circulation during the last glacial maximum. Nature 372, 252 (1994).

42. Adkins, J. F., McIntyre, K. \& Schrag, D. P. The salinity, temperature, and $\delta^{18} \mathrm{O}$ of the glacial deep. Ocean. Sci. 298, 1769-1773 (2002).

43. Hill, D. J., Bolton, K. P. \& Haywood, A. M. Modelled ocean changes at the Plio-Pleistocene transition driven by Antarctic ice advance. Nat. Commun. 8, 14376 (2017).

44. Ferrari, R. et al. Antarctic sea ice control on ocean circulation in present and glacial climates. Proc. Natl Acad. Sci. USA 111, 8753-8758 (2014).

45. Ronge, T. A. et al. Pushing the boundaries: glacial/interglacial variability of intermediate and deep waters in the southwest Pacific over the last 350,000 years. Paleoceanography 30, 23-38 (2015).

46. Jaccard, S. L., Galbraith, E. D., Martínez-García, A. \& Anderson, R. F. Covariation of deep Southern Ocean oxygenation and atmospheric $\mathrm{CO}_{2}$ through the last ice age. Nature 530, 207-210 (2016).

47. Franois, R. et al. Contribution of Southern Ocean surface-water stratification to low atmospheric $\mathrm{CO}_{2}$ concentrations during the last glacial period. Nature 389, 929-935 (1997).

48. Sikes, E. L., Cook, M. S. \& Guilderson, T. P. Reduced deep ocean ventilation in the Southern Pacific Ocean during the last glaciation persisted into the deglaciation. Earth Planet. Sci. Lett. 438, 130-138 (2016).

49. Schmittner, A. Southern Ocean sea ice and radiocarbon ages of glacial bottom waters. Earth Planet. Sci. Lett. 213, 53-62 (2003).

50. Lisiecki, L. \& Raymo, M. A Plio-Pleistocene stack of 57 globally distributed benthic $\delta^{18} \mathrm{O}$ records. Paleoceanography 20, 1-17 (2005).

51. Neil, H. L., Carter, L. \& Morris, M. Y. Thermal isolation of Campbell Plateau, New Zealand, by the Antarctic Circumpolar Current over the past 130 kyr. Paleoceanography 19, PA4008 (2004).

52. Shakun, J. D., Lea, D. W., Lisiecki, L. E. \& Raymo, M. E. An 800-kyr record of global surface ocean and implications for ice volume-temperature coupling. Earth Planet. Sci. Lett. 426, 58-68 (2015).

53. Shackleton, N. J. \& Opdyke, N. D. Oxygen-isotope and paleomagnetic stratigraphy of Pacific Core V28-239 late Pliocene to latest Pleistocene. Geol. Soc. Am. Mem. 145, 449-464 (1976).

54. Koutavas, A. \& Joanides, S. El Niño-Southern oscillation extrema in the holocene and last glacial maximum. Paleoceanography 27, PA4208 (2012).

55. Lalicata, J. J. \& Lea, D. W. Pleistocene carbonate dissolution fluctuations in the eastern equatorial Pacific on glacial timescales: evidence from ODP Hole 1241. Mar. Micropaleontol. 79, 41-51 (2011).

56. Tachikawa, K., Jeandel, C. \& Roy-Barman, M. A new approach to the Nd residence time in the ocean: the role of atmospheric inputs. Earth Planet. Sci. Lett. 170, 433-446 (1999).

57. Moore, T. C., Heath, G. R. \& Kowsmann, R. O. Biogenic sediments of the Panama Basin. J. Geol. 81, 458-472 (1973).

58. Archer, D. E. An atlas of the distribution of calcium carbonate in sediments of the deep sea. Glob. Biogeochem. Cycles 10, 159-174 (1996).

59. Catubig, N. R. et al. Global deep-sea burial rate of calcium carbonate during the Last Glacial Maximum. Paleoceanography 13, 298-310 (1998).

60. Greaves, M. J., Statham, P. J. \& Elderfield, H. Rare earth element mobilization from marine atmospheric dust into seawater. Mar. Chem. 46, 255-260 (1994).

61. Henry, F., Jeandel, C., Dupré, B. \& Minster, J. F. Particulate and dissolved Nd in the western Mediterranean Sea: sources, fate and budget. Mar. Chem. 45, 283-305 (1994).

62. Jeandel, C., Bishop, J. K. \& Zindler, A. Exchange of neodymium and its isotopes between seawater and small and large particles in the Sargasso Sea. Geochim. Cosmochim. Acta 59, 535-547 (1995).

63. Tachikawa, K., Jeandel, C., Vangriesheim, A. \& Dupré, B. Distribution of rare earth elements and neodymium isotopes in suspended particles of the tropical Atlantic Ocean (EUMELI site). Deep Sea Res. Part I Oceanogr. Res. Pap. 46, 733-755 (1999).
64. Dessert, C., Dupré, B., Gaillardet, J., François, L. M. \& Allègre, C. J. Basalt weathering laws and the impact of basalt weathering on the global carbon cycle. Chem. Geol. 202, 257-273 (2003).

65. Jones, M. T. et al. Riverine particulate material dissolution as a significant flux of strontium to the oceans. Earth Planet. Sci. Lett. 355-356, 51-59 (2012).

66. Arsouze, T., Dutay, J. C., Lacan, F. \& Jeandel, C. Reconstructing the Nd oceanic cycle using a coupled dynamical-biogeochemical model. Biogeosciences 6, 2829-2846 (2009).

67. Pearce, C. R., Jones, M. T., Oelkers, E. H., Pradoux, C. \& Jeandel, C. The effect of particulate dissolution on the neodymium (Nd) isotope and Rare Earth Element (REE) composition of seawater. Earth Planet. Sci. Lett. 369-370, 138-147 (2013).

68. Oelkers, E. H. et al. Riverine particulate material dissolution in seawater and its implications for the global cycles of the elements. Comptes Rendus Geosci. 344, 646-651 (2012).

69. Koutavas, A. Sea Surface Temperature Variability in the Eastern Equatorial Pacific During the Last Deglaciation: Multiproxy Geochemical Reconstructions. Doctoral dissertation, Columbia Univ. (2003)

70. Mix, A. C., Le, J. \& Shackleton, N. Benthic foraminiferal stable isotope stratigraphy of site 846: 0-1.8 Ma. Proc. ODP Sci. Res. 138, 839-847 (1995).

71. Marchitto, T. M., Lynch-Stieglitz, J. \& Hemming, S. R. Deep pacific $\mathrm{CaCO}_{3}$ compensation and glacial-interglacial atmospheric $\mathrm{CO}_{2}$. Earth Planet. Sci. Lett. 231, 317-336 (2005).

72. Basak, C., Pahnke, K., Frank, M., Lamy, F. \& Gersonde, R. Neodymium isotopic characterization of Ross Sea Bottom Water and its advection through the southern South Pacific. Earth Planet. Sc. Lett. 419, 211-221 (2015).

73. Amakawa, H. et al. Neodymium isotopic composition and concentration in the Southwest Pacific Ocean. Geochem. J. 47, 409-422 (2013).

74. Grasse, P., Stichel, T., Stumpf, R., Stramma, L. \& Frank, M. The distribution of neodymium isotopes and concentrations in the Eastern Equatorial Pacific: Water mass advection versus particle exchange. Earth Planet. Sc. Lett. 353-354, 198-207 (2012).

75. Jeandel, C., Delattre, H., Grenier, M., Pradoux, C. \& Lacan, F. Rare earth element concentrations and $\mathrm{Nd}$ isotopes in the Southeast Pacific Ocean. Geochem. Geophys. Geosystems 14, 328-341 (2013).

76. Molina-Kescher, M., Frank, M. \& Hathorne, E. South Pacific dissolved Nd isotope compositions and rare earth element distributions: water mass mixing versus biogeochemical cycling. Geochim. Cosmochim. Ac 127, 171-189 (2014).

77. Haley, B. A., Frank, M., Hathorne, E. \& Pisias, N. Biogeochemical implications from dissolved rare earth element and Nd isotope distributions in the Gulf of Alaska. Geochim. Cosmochim. Ac 126, 455-474 (2014).

78. $\mathrm{Wu}, \mathrm{Q}$. et al. New insights into hydrological exchange between the South China Sea and the Western Pacific Ocean based on the Nd isotopic composition of seawater. Deep Sea Res. Part II Top. Stud. Oceanogr. 122, 25-40 (2015)

79. Fröllje, H. et al. Hawaiian imprint on dissolved $\mathrm{Nd}$ and $\mathrm{Ra}$ isotopes and rare earth elements in the central North Pacific: local survey and seasonal variability. Geochim. Cosmochim. Ac 189, 110-131 (2016).

80. Carter, P., Vance, D., Hillenbrand, C. D., Smith, J. A. \& Shoosmith, D. R. The neodymium isotopic composition of waters masses in the eastern Pacific sector of the Southern Ocean. Geochim. Cosmochim. Ac 79, 41-59 (2012).

81. Pahnke, K. et al. GEOTRACES intercalibration of neodymium isotopes and rare earth element concentrations in seawater and suspended particles. Part 2: Systematic tests and baseline profiles. Limnol. Oceanogr. Methods 10, 252-269 (2012).

82. Molina-Kescher, M. et al. The influence of Basaltic Islands on the oceanic REE distribution: a case study from the Tropical South Pacific. Front. Marine Sci. 5, https://doi.org/10.3389/fmars.2018.00050 (2018).

83. Zimmermann, B. et al. The hafnium isotope composition of Pacific Ocean water. Geochim. Cosmochim. Ac 73, 91-101 (2009).

\section{Acknowledgements}

R.H. is supported by Global Change Program of Ministry of Science and Technology of China (2016YFA0600503) and China Postdoctoral Fund (2017M620201) during writing of this paper and the China Scholarship Council for her living cost in Cambridge. The analytical costs were covered by NERC project NE/K005235/1 to A.M.P. We thank the Gulf Coast Repository for providing the sample materials of ODP1241 and ODP846, the Lamont-Doherty Core Repository for providing the sample materials of V21-30 and RC13-114 and R. Anderson for helpful discussion, H. Bostock and H. Neil from the National Institute of Water and Atmospheric Research (New Zealand) to provide the sample materials of SO136-38, J. Clegg, V. Rennie and S. Crowhurst for technical support.

\section{Author contributions}

R.H. and A.M.P. designed the study, R.H. performed the work and R.H. wrote the manuscript with inputs from A.M.P. 


\section{Additional information}

Supplementary Information accompanies this paper at https://doi.org/10.1038/s41467018-07079-z.

Competing interests: The authors declare no competing interests.

Reprints and permission information is available online at http://npg.nature.com/ reprintsandpermissions/

Publisher's note: Springer Nature remains neutral with regard to jurisdictional claims in published maps and institutional affiliations. (c) (i) Open Access This article is licensed under a Creative Commons Attribution 4.0 International License, which permits use, sharing, adaptation, distribution and reproduction in any medium or format, as long as you give appropriate credit to the original author(s) and the source, provide a link to the Creative Commons license, and indicate if changes were made. The images or other third party material in this article are included in the article's Creative Commons license, unless indicated otherwise in a credit line to the material. If material is not included in the article's Creative Commons license and your intended use is not permitted by statutory regulation or exceeds the permitted use, you will need to obtain permission directly from the copyright holder. To view a copy of this license, visit http://creativecommons.org/ licenses/by/4.0/.

(C) The Author(s) 2018 